\title{
PERAN MEDIASI CITRA MEREK DAN PERSEPSI RISIKO PADA HUBUNGAN ANTARA ELECTRONIC WORD OF MOUTH (E-WOM) DAN MINAT BELI (STUDI PADA KONSUMEN KOSMETIK E-COMMERCE DI SOLO RAYA)
}

\author{
Zahra Noor Eriza \\ Magister Manajemen, Fakultas Ekonomi dan Bisnis, \\ Universitas Sebelas Maret Surakarta \\ E-mail: neyrhiza@gmail.com
}

\begin{abstract}
Electronic word of mouth (E-WOM) has been used by consumers to dig up information about a product. Information obtained from various sources on the internet will affect consumer perception of brand image, perceived risk, and encourage consumer purchase intention. This study analyzed the mediating role of brand image and the perceived risk on the relationship between E-WOM and purchase intention. The sample consisted of 149 consumers in Solo Raya who have recently made cosmetics purchases via e-commerce. The results showed that E-WOM influences positively on purchase intention and brand image. Regression testing of mediation concluded that the brand image as a partial mediation for E-WOM against purchase intention. These results mean that the activity of reading product reviews on the internet will provide information about the benefits and advantages of the product so that consumers will feel confident that they chose the right products and encourage consumers purchase intention. While E-WOM is influencing negatively the perceived risk but not mediating E-WOM against Purchase Intention.
\end{abstract}

Keywords: E-WOM, Purchase Intention, Brand Image, Perceived Risk

\section{ABSTRAK}

Electronic word of mouth (E-WOM) banyak dimanfaatkan konsumen untuk menggali informasi mengenai suatu produk. Informasi yang diperoleh dari berbagai sumber di internet akan mempengaruhi persepsi konsumen terhadap citra merek, risiko dan mendorong minat beli konsumen. Penelitian ini menganalisis peran mediasi citra merek dan persepsi risiko pada hubungan E-WOM dan minat beli. Sampel penelitian ini terdiri dari 149 konsumen di Solo Raya yang telah melakukan pembelian kosmetik melalui e-commerce. Hasil penelitian menunjukkan bahwa E-WOM berpengaruh positif terhadap minat beli dan citra merek. Pengujian regresi mediasi menyimpulkan bahwa citra merek memediasi secara parsial hubungan E-WOM dan minat beli. Hasil tersebut mengartikan bahwa aktivitas membaca ulasan produk di internet akan memberikan informasi mengenai manfaat dan keunggulan produk sehingga konsumen akan merasa yakin bahwa mereka memilih produk yang tepat dan mendorong minat beli konsumen. Sedangkan E-WOM berpengaruh negatif terhadap persepsi risiko namun tidak memediasi hubungan E-WOM dan minat beli.

Kata kunci: E-WOM, Minat Beli, Citra Merek, Persepsi Risiko.

\section{A. Pendahuluan}

Indonesia merupakan negara dengan pengguna internet terbanyak di Asia Tenggara. Menurut data We are
Social (2016), sebanyak 66 juta orang memanfaatkan mobile device sebagai perangkat untuk mengakses internet. Hal ini dijadikan peluang bagi para pelaku 
bisnis untuk untuk melakukan transaksi perdagangan melalui internet, yang dikenal dengan istilah electronic commerce atau e-commerce. Pada tahun 2016 sebanyak 23,8 juta orang di Indoneisa bertransaksi jual beli secara online. Melalui internet, konsumen dapat mencari beragam informasi mengenai suatu produk. Aktivitas ini memungkinkan terjadinya sebuah komunikasi mulut ke mulut atau word-ofmouth (WOM) yang tidak hanya menjadi sebuah bentuk komunikasi person-to-person atau interpersonal yang membahas sebuah produk, layanan ataupun merek, tetapi menjadi suatu bentuk komunikasi word-ofmouth (WOM) yang kemudian merambat secara mendunia melalui internet dan ini sering disebut Electronic Word of Mouth (E-WOM) (Jalilvand, 2012).

Komunikasi E-WOM melalui media elektronik mampu membuat konsumen tidak hanya mendapatkan informasi mengenai produk dan jasa yang berasal dari orang yang dikenal, namun juga dapat berasal dari orang lain yang berbeda area geografisnya yang memiliki pengalaman terhadap produk atau jasa yang dimaksud (Christy, 2010). Informasi yang diperoleh melalui E-WOM dapat digunakan sebagai pertimbangan mengenai informasi sebelum pembelian produk (Adjei et al.,2009; Zhu dan Zhang, 2010; Lee dan Koo, 2012) dan kemudian mengarahkan sikap konsumen (Lee at al., 2009; Jalilvand et al., 2012), yang mempengaruhi citra merek suatu produk dan minat beli konsumen (Elseidi, 2016).

Di lain pihak, aktivitas pembelian produk melalui e-commerce tidak akan terjadi jika konsumen tidak memiliki kepercayaan terhadap situs belanja e-commerce (Mayer et.al., 1995 ). Konsumen akan menghadapi rasa ketidakpastian saat memutuskan untuk melakukan pembelian melalui perusahaan online, seperti ketidakpastian transaksi yang berhasil, kualitas produk yang diterima, serta garansi pengembalian, hal ini disebut dengan persepsi risiko (Gurung. 2006)

Menurut laporan AC Nielsen Consumer \& Media View Survey pada kuartal II tahun
2011-2015, fashion adalah produk yang paling banyak dibeli konsumen melalui e-commerce di mana pada tahun 2015 penjualan online produk kecantikan di Indonesia mencapai 139 juta dolar. Jumlah ini tumbuh 35,7 persen dari tahun lalu. Salah satu produk yang banyak diminati adalah kosmetik. Kosmetik sendiri diminati karena tujuannya untuk membersihkan, mempercantik, membuat lebih menarik atau mengubah penampilan. Di antara produk yang termasuk di dalam definisi ini adalah pelembab kulit, parfum, lipstik, pemoles kuku, riasan mata dan wajah, sampo, produk pengeriting, pewarna rambut dan deodoran serta zat apapun yang dimaksudkan untuk digunakan sebagai komponen dari produk kosmetik. Berdasarkan uraian di atas maka penelitian ini bertujuan untuk mengetahui: pengaruh electronic word of mouth (E-WOM) terhadap minat beli konsumen; mengetahui pengaruh electronic word of mouth (E-WOM) terhadap citra merek; pengaruh citra merek terhadap minat beli konsumen; pengaruh electronic word of mouth (E-WOM) terhadap minat beli konsumen dengan citra merek sebagai variabel mediasi; pengaruh electronic word of mouth (E-WOM) terhadap persepsi risiko; pengaruh persepsi risiko terhadap minat beli konsumen; serta pengaruh electronic word of mouth (E-WOM) terhadap minat beli konsumen dengan persepsi risiko sebagai variabel mediasi.

\section{B. Tinjauan Pustaka dan Pengembangan Hipotesis}

\section{Electronic Word of Mouth (E- WOM)}

Word of mouth adalah saluran komunikasi informal utama konsumen. Hal ini mempengaruhi keputusan jangka pendek dan jangka panjang konsumen untuk membeli suatu produk. Dengan demikian, word of mouth memainkan peran penting dalam perilaku konsumen (Herr et al. 1991; Bone, 1995). Word of mouth dapat mempengaruhi beberapa kondisi seperti kesadaran, persepsi, sikap, niat dan perilaku (Buttle, 1998). Hal ini menjelaskan bahwa 
komunikasi dari mulut ke mulut dapat mempengaruhi beberapa macam kondisi, yaitu kesadaran, harapan, persepsi, sikap, keinginan berbuat, dan perilaku. Perilaku yang dimaksudkan di sini adalah perilaku konsumen dalam melakukan keputusan pembelian yang diawali dari minat konsumen terhadap suatu produk atau jasa.

\section{Minat Beli}

Minat beli menurut Kotler (2005) adalah sesuatu yang timbul setelah menerima rangsangan dari produk yang dilihatnya, dari sana timbul ketertarikan untuk membeli agar dapat memilikinya. Minat beli konsumen akan timbul dengan sendirinya jika konsumen sudah merasa tertarik atau memberikan respon yang positif terhadap apa yang ditawarkan oleh si penjual. Minat beli juga merupakan instruksi diri konsumen untuk melakukan pembelian atas suatu produk, melakukan perencanaan, mengambil tindakan-tindakan yang relevan seperti mengusulkan, merekomendasikan, memilih dan akhirnya mengambil keputusan untuk melakukan.

\section{Hubungan Electronic Word of Mouth dan Minat Beli}

Saat ini, cara konsumen berinteraksi satu sama lain telah berubah, karena perubahan luas dalam teknologi dan internet, yang memfasilitasi konsumen untuk berbagi informasi, saran dan opini terkait pengalaman konsumsi melalui online atau disebut electronic word of mouth (E-WOM) (Godes dan Mayzlin, 2004; Brown et al, 2007; . Xia dan Bechwati,2008). Di dalam aktivitas E-WOM, opini yang dituliskan konsumen dapat berupa opini positif maupun negarif. E-WOM yang positif dapat memunculkan dan meningkatkan minat beli pada kosnumen untuk membeli produk. Sedangkan E-WOM yang negatif akan menurunkan minat beli konsumen. Hal tersebut disebabkan konsumen yang akan membeli suatu produk telah membaca melalui blog atau web terpercaya. Sehingga E-WOM memiliki pengaruh yang besar terhadap minat beli (Samuel dan Lianto,
2014)

$\mathrm{H}_{1}$ : Terdapat pengaruh positif electonic word of mouth (E-WOM) terhadap minat beli konsumen.

\section{Citra Merek}

Tjiptono (2005) menjelaskan bahwa citra merek merupakan deskripsi tentang asosiasi dan keyakinan konsumen terhadap merek tertentu. Citra merek mendefinisikan segala hal yang terkait dengan merek yang ada di ingatan konsumen yang mempresentasikan keseluruhan persepsi konsumen terhadap merek yang terbentuk karena informasi dan pengalaman konsumen terhadap suatu merek. Kesan-kesan positif yang diperoleh pelanggan merupakan pengalaman dan pengetahuan yang didapatnya dari merek tersebut. Maka persepsi maupun pemahaman pelanggan terhadap suatu merek tergantung pada kemampuan pelanggan dalam mengidentifikasi bermacam informasi mengenai merek tersebut, serta kemampuan pelanggan untuk menyimpan informasi dari merek tersebut dalam ingatannya. Pemahaman pelanggan terhadap suatu merek merupakan cerminan dari penilaian pelanggan atas merek produk-produk yang ditawarkan. (Keller, 2008)

\section{Hubungan Electronic Word of Mouth (E-WOM), Minat Beli dan Citra Merek}

Para peneliti menunjukkan bahwa komentar atau opini konsumen lain di internet mempengaruhi sikap konsumen terhadap merek, seperti komentar yang positif mengenai merek, dapat mengarahkan sikap menjadi lebih tertarik terhadap merek tersebut, sementara kehadiran komentar negatif mengarah ke pengaruh negatif terhadap merek (Lee et al., 2009). Maka, niat pembelian konsumen akan ditentukan berdasarakan persepsi nilai yang diberikan oleh merek tersebut. Penelitian yang dilakukan Aaker dan Keller (2007), menemukan bahwa sebuah merek dengan citra positif meningkatkan loyalitas konsumen dan kepercayaan serta memperkuat niat beli konsumen. 
Pemaparan di atas sesuai dengan temuan Torlak et al., (2014) dan Charo et al., (2015) yang menunjukkan bahwa ada hubungan positif yang signifikan antara E-WOM dengan citra merek dan niat beli. Demikian juga, Jalilvand dan Samiei (2012) setuju bahwa E-WOM adalah salah satu faktor yang paling efektif mempengaruhi citra merek. Lin etal,.(2013)mengungkapkan bahwa keterlibatan citra merek memediasi hubungan antara E-WOM dan minat beli.

$\mathrm{H}_{2}$ : Terdapat pengaruh positif electonic word of mouth (E-WOM) terhadap citra merek

$\mathrm{H}_{3}$ : Terdapat pengaruh positif citra merek terhadap minat beli

$\mathrm{H}_{4}$ : Citra merek memediasi hubungan electonic word of mouth (E-WOM) dan minat beli.

\section{Persepsi Risiko}

Secara teori menurut Peter dan Olson (2012), persepsi risiko (perceived risk) merupakan konsekuensi yang tidak diharapkan yang ingin dihindari konsumen saat membeli dan menggunakan produk. Schiffman dan Kanuk (2008) mendefinikan risiko sebagai suatu situasi di mana pembuat keputusan memiliki pengetahuan apriori konsekuensi yang merugikan dan kemungkinan terjadinya. Schiffman dan Kanuk (2008) juga menjelaskan, terdapat tipe risiko utama yang dirasakan konsumen ketika mengambil keputusan pembelian meliputi, functional risk, physical risk, social risk, financial risk, psychological risk dan time risk

\section{Hubungan Electronic Word of Mouth (E-WOM), Persepsi Risiko dan Minat Beli}

Penelitian yang dilakukan Indiani et al., (2015) menunjukkan aktivitas E-WOM memiliki pengaruh negatif terhadap persepsi risiko konsumen yang akan melakukan pembelian produk secara online. Persepsi risiko menunjuk pada rasa ketidakpastian yang dialami oleh konsumen saat akan memutuskan melakukan pembelian secara online (Gurung. 2006).
Penelitian Gurung (2006), menyatakan bahwa persepsi risiko tidak berpengaruh terhadap minat pembelian melalui sistem e-commerce. Penelitian yang dilakukan menunjukkan tidak ada dukungan untuk argumen yang menyatakan bahwa semakin tinggi persepsi risiko menyebabkan niat yang kecil untuk melakukan transaksi dalam sistem e-commerce. Informasi yang diberikan melalui E-WOM kemudian digunakan sebagai pertimbangan bagi konsumen sebelum melakukan pembelian produk. Tingginya aktivitas E-WOM akan menurunkan persepsi risiko konsumen,sehingga mendorong minat pembelian secara online (Indiani et al., 2015). Penelitian Indiani et al., (2015) juga membuktikan bahwa persepsi risiko memediasi hubungan E-WOM dan minat beli konsumen.

$\mathrm{H}_{5}$ : Terdapat pengaruh negatif electronic word of mouth (E-WOM) terhadap persepsi risiko.

$\mathrm{H}_{6}$ : Terdapat pengaruh negatif persepsi risiko terhadap minat beli konsumen.

$\mathrm{H}_{7}$ : Persepsi risiko memediasi hubungan electonic word of mouth (E-WOM) dan minat beli konsumen.

\section{Gambar 1. Model Penelitian}

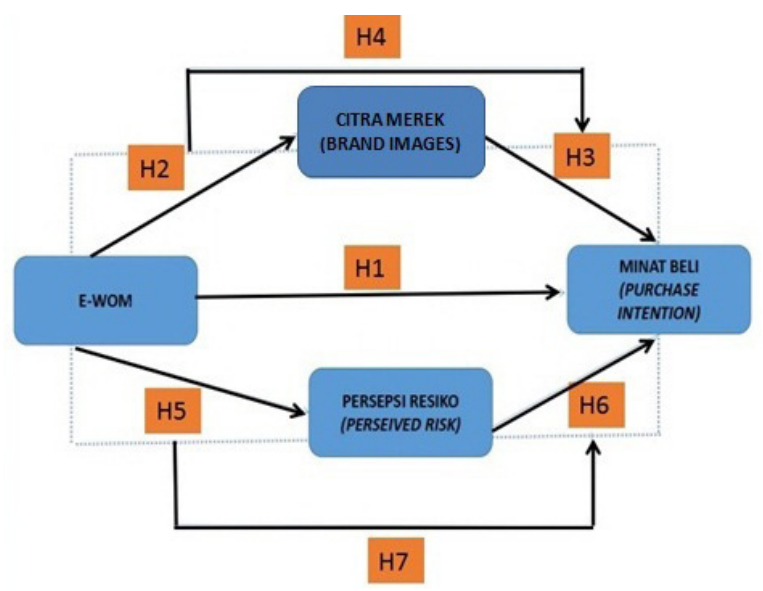

\section{Metode Penelitian}

Populasi yang digunakan adalah seluruh konsumen yang melakukan pembelian kosmetik melalui e-commerce di wilayah Solo Raya dengan jumlah sampel 149 
responden dengan teknik pengambilan sampel convenience sampling. Penelitian ini menggunakan teknik pengumpulan data berupa kuesioner atau angket dan dengan skala likert 1-5 (Sugiono, 2010). Uji hipotesis mediasi menggunakan metode Baron dan Kenny (1986) yang menguji pengaruh mediasi pada hubungan variabel independen dan variabel dependen menggunakan model regresi. Uji validitas menggunakan confirmatory factor analysis (CFA) dengan software SPSS. Untuk mengukur reliabilitas, peneliti menggunakan alat ukur Cronbach Alpha.

\section{Profil Responden}

Sebagian besar responden berjenis kelamin perempuan dengan jumlah 119 orang (79,9\%). Berdasarkan usia, konsumen kosmetik E-Commerce di Solo Raya paling banyak berusia 21-30 tahun yaitu 72 orang (48,3\%). Mayoritas konsumen berstatus sebagai pelajar atau mahasiswa dengan jumlah 81 orang $(54,4 \%)$ dengan pendidikan minimal SMA (65 orang atau 43,6\%). Rata-rata penghasilan konsumen kosmetik E-Commerce di Solo Raya yang paling banyak berkisar $f$ Rp 1.500.000,00 dengan jumlah 85 orang (57\%).

Tabel 1. Distribusi Frekuensi Karakteristik Responden

\begin{tabular}{lcc}
\hline a. Jenis Kelamin & Frekuensi & Persentase (\%) \\
\hline Perempuan & 119 & 79,9 \\
Laki-Laki & 30 & 20,1 \\
\hline b. Usia & & \\
\hline$\leq 20$ tahun & 63 & 42,3 \\
21-30 tahun & 72 & 48,3 \\
31-40 tahun & 14 & 9,4 \\
\hline c. Pekerjaan & & \\
\hline Pelajar/ Mahasiswa & 81 & 54,4 \\
Karyawan Swasta & 26 & 17,4 \\
Wiraswasta & 19 & 12,8 \\
PNS & 8 & 5,4 \\
Lain-Lain & 15 & 10,1 \\
\hline d. Pendidikan & & \\
\hline SMA & 65 & 43,6 \\
D3 & 25 & 16,8 \\
S1 & 50 & 33,6 \\
S2 & 9 & 6,0 \\
\hline e. Penghasilan & & \\
\hline S Rp 1.500.000,00 & 85 & 57,0 \\
Rp 1.500.001,00 - Rp 2.000.000,00 & 25 & 16,8 \\
Rp 2.000.001,00 - Rp 3.000.000,00 & 17 & 11,4 \\
$\geq$ Rp 3.000.000,00 & 22 & 14,8 \\
\end{tabular}

\section{Hasil dan Pembahasan}

Pengujian validitas dilakukan dengan Confirmatory Factor Analysis (CFA), untuk mengukur keempat variabel yaitu word of mouth (E-WOM), minat beli, citra merek dan persepsi risiko dengan baik. 
Tabel 2. KMO and Bartlett's Test

Kaiser-Meyer-Olkin Measure of Sampling Adequacy.

Bartlett's Test of Sphericity

df

Sig. , 000

Pada Tabel 2, menunjukkan nilai KMO Measure of Sampling Adequancy (MSA) dalam penelitian ini adalah sebesar 0, 816 . Karena nilai MSA di atas 0,5 serta nilai Barlett
Test dengan Chi-Square signifikan 0,000 dapat disimpulkan bahwa uji analisis faktor dapat dilanjutkan dan hasil analisis faktor nampak pada Tabel 3.

Tabel 3. Hasil Analisis Faktor

\begin{tabular}{|c|c|c|c|c|}
\hline \multicolumn{5}{|c|}{ Rotated Component Matrix } \\
\hline & \multicolumn{4}{|c|}{ Component } \\
\hline & 1 & 2 & 3 & 4 \\
\hline $\mathrm{X} .1$ & 826 &,- 063 & 105 & 248 \\
\hline$X .2$ &, 711 & ,398 &, 213 &,- 003 \\
\hline X.3 & ,770 &,- 021 &, 012 & 237 \\
\hline$X .4$ &, 724 &, 502 &, 051 &,- 022 \\
\hline X.5 & ,613 &, 149 &, 095 &, 118 \\
\hline$X .6$ & 440 & 615 &, 094 &,- 014 \\
\hline Y.1 & 177 &, 014 &,- 015 & ,746 \\
\hline Y.2 &,- 013 &, 564 &, 374 & 144 \\
\hline Y.3 & 164 &, 347 &, 029 & ,646 \\
\hline M1.1 &, 086 & 683 &,- 026 &, 143 \\
\hline M1.2 &, 089 & 175 & , 142 & 699 \\
\hline M1.3 & 105 &, 564 &,- 012 &, 300 \\
\hline M2.1 &,- 068 &,- 052 &,- 762 & ,012 \\
\hline M2.2 &,- 149 &,- 164 &,- 708 &,- 053 \\
\hline M2.3 & ,078 &,- 057 & ,787 & ,081 \\
\hline
\end{tabular}

Extraction Method: Principal Component Analysis.

Rotation Method: Varimax with Kaiser Normalization.

a. Rotation converged in 6 iterations.

Tabel 4 menunjukkan hasil pengujian reliabilitas pada keempat variabel diperoleh informasi bahwa semua variabel memiliki nilai Cronbach Alpha diantara 0,6 - 0,799.
Dengan demikian keempat variabel yang digunakan dalam penelitian reliabilitasnya dapat diterima.

Tabel 4. Hasil Pengujian Reliabilitas

\begin{tabular}{lc}
\hline \multicolumn{1}{c}{ Variabel } & Cronbach Alpha \\
\hline E-WOM & 0,797 \\
Minat Beli & 0,767 \\
Citra Merek & 0,645 \\
Persepsi Risiko & 0,639 \\
\hline
\end{tabular}




\section{Pengujian Hipotesis}

Berdasarkan hasil uji hipotesis 1 sampai hipotesis 7 maka dapat disusun kesimpulan analisis secara menyeluruh dan ditunjukkan pada Tabel 5.

\section{Pengaruh Electronic Word of Mouth (E-WOM) terhadap Minat Beli Konsumen}

Hasil penelitian yang dilakukan menunjukkan bahwa E-WOM memiliki nilai sig sebesar 0,000 atau nilai sig kurang dari 0,05. Berdasarkan hasil tersebut dapat disimpulkan bahwa E-WOM berpengaruh signifikan pada minat beli konsumen, sehingga hipotesis 1 diterima. Hasil tersebut menjelaskan bahwa aktivitas membaca review atau ulasan produk kosmetik dari konsumen lain melalui internet, akan mendorong minat pembelian produk atau merek tersebut, melakukan pembelian ulang di masa yang akan datang dan mendorong konsumen memberikan rekomendasi mengenai produk terhadap konsumen lain. Pernyataan tersebut sejalan dengan penelitian yang dilakukan oleh Jalilvand (2012) yang menyatakan bahwa E-WOM mendorong minat beli konsumen. Samuel dan Lianto (2014) juga menjelaskan, bahwa E-WOM positif dapat memunculkan dan meningatkan minat beli pada konsumen untuk membeli suatu produk. Sedangkan
E-WOM negatif akan menurunkan minat beli produk.

\section{Pengaruh Electronic Word of Mouth (E-WOM) terhadap Citra Merek}

Hasil penelitian yang dilakukan menunjukkan bahwa E-WOM memiliki nilai sig sebesar 0,000 atau nilai sig kurang dari 0,05. Berdasarkan hasil tersebut dapat disimpulkan bahwa E-WOM berpengaruh signifikan pada citra merek, sehingga hipotesis 2 diterima. Hasil tersebut menjelaskan bahwa aktivitas membaca review atau ulasan produk kosmetik dari konsumen lain melalui internet, akan menimbulkan keyakinan pada konsumen mengenai kualitas dan manfaat dari produk tersebut.

Pernyataan tersebut sejalan dengan penelitian yang dilakukan Gruen etal., (2006) dan Jalilvand (2012) bahwa komunikasi E-WOM disinyalir memberikan informasi yang relatif dapat diandalkan sehingga menimbulkan rasa percaya konsumen terhadap produk. Riyandika (2013) dalam penelitiannya juga menyatakan bahwa E-WOM berpengaruh positif terhadap citra merek. la menyatakan bahwa semakin sering aktivitas pencarian terhadap suatu informasi maka akan mempengaruhi suatu pandangan atau image terhadap suatu merek di benak konsumen.

Tabel 5. Kesimpulan Hasil Hipotesis

\begin{tabular}{|c|c|c|c|c|}
\hline \multicolumn{5}{|c|}{ Pengaruh } \\
\hline $\mathrm{H}$ & Antar Variabel & $\begin{array}{l}\text { Langsung } \\
\text { (Sig) }\end{array}$ & $\begin{array}{l}\text { Tak Langsung } \\
\text { (Sig) }\end{array}$ & Kesimpulan \\
\hline 1 & $\mathrm{E}-\mathrm{WOM} \rightarrow \mathrm{MB}$ & 0,000 & \multicolumn{2}{|r|}{ Berpengaruh Positif Signifikan } \\
\hline 2 & $\mathrm{E}-\mathrm{WOM} \rightarrow \mathrm{CM}$ & 0,000 & \multicolumn{2}{|r|}{ Berpengaruh Positif Signifikan } \\
\hline 3 & $\mathrm{CM} \rightarrow \mathrm{MB}$ & 0,000 & \multicolumn{2}{|r|}{ Berpengaruh Positif Signifikan } \\
\hline 4 & $\begin{array}{c}\mathrm{E}-\mathrm{WOM} \rightarrow \mathrm{CM} \\
\rightarrow \mathrm{MB}\end{array}$ & & $\begin{array}{l}0,004 \\
0,000\end{array}$ & Berpengaruh Positif Signifikan \\
\hline 5 & E-WOM $\rightarrow$ PR & 0,007 & & Berpengaruh Negatif Signifikan \\
\hline 6 & $\mathrm{PR} \rightarrow \mathrm{MB}$ & 0,021 & & Berpengaruh Negatif Signifikan \\
\hline 7 & $\begin{array}{l}\mathrm{E}-\mathrm{WOM} \rightarrow \mathrm{PR} \\
\quad \rightarrow \mathrm{MB}\end{array}$ & & $\begin{array}{l}0,000 \\
0,178\end{array}$ & $\begin{array}{l}\text { PR Tidak Berpengaruh Signifikan } \\
\text { Variabel "PR" bukan sebagai pemediasi }\end{array}$ \\
\hline \multicolumn{4}{|c|}{$\begin{array}{l}\text { Keterangan: } \\
\text { Dianggap signifikan jika nilai Sig }<0,05\end{array}$} & $\begin{array}{ll}\text { CM } & \text { Citra Merek } \\
\text { PR } & \text { Persepsi Risiko } \\
\text { MB } & \text { Minat Beli }\end{array}$ \\
\hline
\end{tabular}




\section{Pengaruh Citra Merek terhadap Minat Beli Konsumen}

Hasil penelitian yang dilakukan menunjukkan bahwa citra merek memiliki nilai sig sebesar 0,000 atau nilai sig kurang dari 0,05. Berdasarkan hasil tersebut dapat disimpulkan bahwa citra merek berpengaruh signifikan pada minat beli konsumen, sehingga hipotesis 3 diterima. Hasil tersebut menjelaskan bahwa keyakinan konsumen terhadap citra nilai kualitas dan manfaat suatu produk atau merek kosmetik dapat meningkatkan loyalitas konsumen, kepercayaan dan memperkuat minat beli konsumen. Jalilvand (2012) menemukan bahwa citra merek memiliki pengaruh secara langsung terhadap minat beli dan juga pengaruh tidak langsung dari E-WOM terhadap minat beli itu sendiri. Hal ini sesuai dengan penelitian yang dilakukan oleh Aaker dan Keller (1990), bahwa ketika konsumen mempertimbangkan untuk membeli produk, minat pembelian mereka ditentukan berdasarkan persepsi nilai yang diberikan merek tersebut. Jika merek tersebut memberikan banyak nilai atribut, manfaat, sosial dan pemakaian, maka semakin tinggi minat beli konsumen.

\section{Citra Merek Memediasi Hubungan Electronic Word of Mouth (E-WOM) terhadap Minat Beli Konsumen.}

Citra merek memediasi secara parsial hubungan E-WOM dan minat beli konsumen. Mediasi citra merek dikatakan parsial, karena variabel indepedenden E-WOM dapat mempengaruhi variabel dependen minat beli secara langsung, maupun melalui variabel mediasi citra merek. Hal tesebut dibuktikan dengan nilai sig pada hubungan E-WOM pada minat beli konsumen bernilai 0,004 atau kurang dari 0,05 (sebelumnya nilai sig kurang dari 0,05), sedangkan nilai sig pada hubungan Citra Merek pada minat beli konsumen bernilai tetap 0,000 atau kurang dari 0,05. Berdasarkan hasil tersebut dapat disimpulkan bahwa hipotesis $\mathbf{4}$ diterima. Mediasi parsial pada hipotesis 4 menjelaskan dua model.
Model pertama adalah hubungan langsung E-WOM pada minat beli konsumen. Aktivitas membaca review atau ulasan produk kosmetik tertentu dari konsumen lain melalui internet, akan memberikan keyakinan pada diri konsumen bahwa mereka memilih produk yang baik, yang kemudian mendorong konsumen tersebut untuk melakukan pembelian produk. Hal tersebut sejalan dengan pernyataan Jalilvand (2012), Torlak et al., (2014) dan Charo et al., (2015) yang menunjukkan bahwa ada hubungan positif yang signifikan antara E-WOM dengan minat beli. Model yang kedua adalah hasil prediksi peran variabel Citra Merek sebagai mediator hubungan E-WOM pada minat beli. Ketika konsumen mendapatkan informasi yang positif mengenai suatu produk kosmetik yang berasal dari konsumen lain yang telah menggunakan produk tersebut sebelumnya melalui intenet, persepsi konsumen terhadap keunggulan dan manfaat produk kosmetik tersebut akan semakin tinggi. Konsumen juga meyakini bahwa mereka memilih produk yang tepat. Sehingga minat konsumen untuk melakukan pembelian semakin besar. Berdasarkan pernyataan tersebut maka prediksi bahwa variabel citra merek mampu menjadi mediator hubungan E-WOM pada minat beli konsumen telah terbukti.

\section{Pengaruh Electronic Word of Mouth (E-WOM) terhadap Persepsi Risiko}

Hasil penelitian yang dilakukan menunjukkan bahwa E-WOM memiliki nilai sig sebesar 0,007 atau nilai sig kurang dari 0,05. Berdasarkan hasil tersebut dapat disimpulkan bahwa E-WOM berpengaruh signifikan pada persepsi risiko, sehingga hipotesis $\mathbf{5}$ diterima. Hasil tersebut menjelaskan bahwa aktivitas membaca review atau ulasan produk kosmetik dari konsumen lain melalui internet, akan mengurangi keraguan atau ketidakyakinan konsumen terhadap kerugian yang mungkin dialami konsumen ketika membeli produk kosmetik di internet. Kerugian yang dialami dapat berupa kerugian material seperti 
keuangan atau non material seperti waktu dan psikologis.

Hal ini sesuai dengan penelitian Indiani et al., (2015) yang menunjukkan bahwa aktivitas E-WOM dapat menurunkan persepsi risiko konsumen. AghekyanSimonian (2012) menemukan bahwa semakin tinggi kepercayaan konsumen terhadap informasi produk, maka akan menurunkan persepsi risiko dalam benak konsumen.

\section{Pengaruh Persepsi Risiko terhadap Minat Beli Konsumen}

Hasil penelitian yang dilakukan menunjukkan bahwa persepsi risiko memiliki nilai sig sebesar 0,021 atau nilai sig kurang dari 0,05. Berdasarkan hasil tersebut dapat disimpulkan bahwa persepsi risiko berpengaruh signifikan pada minat beli konsumen, sehingga hipotesis 6 diterima. Hasil tersebut menjelaskan bahwa ketika konsumen memahami bahwa terdapat kemungkinan yang rendah terjadi kerugian yang dapat dialami konsumen ketika melakukan pembelian kosmetik melalui e-commerce, maka hal tersebut akan mendorong minat pembelian konsumen. Aghekyan-Simonian (2012) menyatakan persepsi risiko yang rendah akan membawa sikap positif terhadap minat pembelian. Begitu pula sebaliknya, Kim et al., (2008) menyatakan bahwa ketika konsumen berada pada ketidakpastian dan kemungkinana menghadapi kerugian, konsumen akan enggan untuk melakukan transaksi online.

\section{Persepsi Risiko Memediasi Electonic Word of Mouth (E-WOM) dan Minat Beli Konsumen.}

E-WOM tidak berpengaruh signifkan pada minatbelikonsumen dengan dimediasi oleh persepsi citra risiko. Hal tesebut dibuktikan dengan nilai sig pada hubungan E-WOM pada minat beli konsumen bernilai 0,000 atau kurang dari 0,05), sedangkan nilai sig pada hubungan persepsi risiko pada minat beli konsumen bernilai 0,178 atau lebih dari 0,05. Berdasarkan hasil tersebut dapat disimpulkan bahwa hipotesis 7 ditolak. Hal ini menjelaskan bahwa aktivitas membaca review atau ulasan konsumen lain mengenaisuatu produk atau merek kosmetik melalui internet dapat mendorong minat pembelian. Namun, rasa ketidakpastian atau kemungkinana menghadapi risiko kerugian yang akan dialami oleh konsumen tidak menjadi mediator aktivitas membaca review di internet dengan minat melakukan pembelian melalui e-commerce. Penelitian ini tidak mendukung penelitian Indiani et al., (2015) yang menunjukkan bahwa persepsi risiko memediasi hubungan E-WOM dengan minat beli konsumen.

Secara keseluruhan disimpulkan bahwa E-WOM dapat mempengaruhi minat beli secara langsung serta dapat juga dimediasi citra merek. Sedangkan persepsi risiko tidak memediasi hubungan antara E-WOM dan minat beli.

\section{E. Kesimpulan}

Berdasarkan hasil analisis uji hipotesis yang telah dilakukan maka dapat diambil kesimpulan bahwa electronic word of mouth (E-WOM) berpengaruh pada minat beli dengan dimediasi secara parsial oleh citra merek. Hasil tersebut mengartikan bahwa aktivitas membaca ulasan produk di internet akan memberikan informasi mengenai manfaat dan keunggulan produk. Konsumen akan merasa yakin bahwa ia memilih produk yang tepat. Sehingga akan mendorong minat beli konsumen. Sedangkan electronic word of mouth (E-WOM) berpengaruh pada minat beli tidak dimediasi oleh persepsi risiko. Hal tersebut mengartikan bahwa pengaruh aktivitas membaca ulasan produk kosmetik di internet terhadap minat beli konsumen tidak berhubungan dengan rasa ketidakpastian konsumen ketika membeli produk melalui e-commerce.

\section{F. Keterbatasan dan Rekomendasi}

Penelitian ini hanya menunjukkan hubungan electronic word of mouth (E-WOM), minat beli, citra merek dan persepsi risiko pada konsumen produk 
kosmetik yang melakukan transaksi melalui e-commerce secara keseluruhan dan bukan berdasarkan perbedaan merek kosmetik, jenis kosmetik dan website e-commerce atau online shop. Obyek penelitian terbatas pada konsumen kosmetik e-commerce di wilayah Solo Raya, sehingga memungkinkan adanya perbedaan hasil penelitian dan kesimpulan jika penelitian dilakukan pada obyek penelitian yang berbeda. Hasil penelitian ini hanya didasarkan pada jawaban responden melalui kuesioner yang disebarkan serta tidak didukung dengan adanya hasil wawancara secara mendalam.

Peneliti selanjutnya dapat menunjukkan hubungan electronic word of mouth (E-WOM), minat beli, citra merek dan persepsi risiko pada konsumen produk kosmetik yang melakukan transaksi melalui e-commerce, secara spesifik berdasarkan perbedaan merek kosmetik, jenis kosmetik dan website e-commerce atau online shop. Hal ini diharapkan informasi yang diberikan akan lebih mendetail sesuai dengan perbedaan karakteristik merek kosmetik, jenis kosmetik dan website e-commerce. Peneliti selanjutnya dapat memilih obyek penelitian pada konsumen kosmetik e-commerce di wilayah yang lebih luas, sehingga memiliki tingkat variasi yang lebih kompleks Peneliti juga dapat mengembangkan penelitian ini dengan menggunakan metode lain dalam meneliti electronic word of mouth (E-WOM), minat beli, citra merek dan persepsi risiko misalnya melalui wawancara mendalam terhadap responden, sehingga informasi yang diperoleh dapat lebih bervariasi daripada kuesioner yang jawabannya telah tersedia.

\section{DAFTAR PUSTAKA}

AC Nielsen Consumer \& Media View Survey. (2015). Laporan Kuartal II 2011-2015.

Adjei, M., Noble, S., dan Noble, C.(2009). The influence of C2C Communications in Online Brand Communities on Customer Purchase Behavior. Journal of the Academy of Marketing Science. 38(5), pp.634-653.

Baron, R.M, dan Kenny, D.A. (1986). The Moderator-Mediator Variable Distiction in Social Psycological Research : Conceptual, Strategic, and Statistical Considerations. Journal of Personality and Social Psychology. 51 (6),1173-1182

Christy M,K,C., dan Lee-Matthew, K,O. (2010). What's Drives Consumers to Spread Electronic Word of Mouth in Online Consumer-Opinion Platforms. Article Of Decision Support System.

Davis, D.F., Golicic, S.L. dan Marquardt, A. (2009). Measuring Brand Equity for Logistics Services. International Journal of Logistics Management. Vol. 20 No. 2, pp. 201-12.

Elseidi, R dan Dina, E. (2016). Electronic Word of Mouth on Consumer Brand Attitudes, Brand Image and Purchase Intention: an Empirical Study in Egypt. The Business and Management Review.Vol.7.No 5,pp514-522

Ghozali,I. (2006). Aplikasi Multivariat dengan Program SPSS. Semarang : badan Pe n e r b it Undip

Jalilvand, M,R.(2012). The Effect of Electronic Word Of-Mouth on Brand Image and Purchase Intention. Journals Of Marketing Inteligence And Planning. Vol.30, Iss:4, hal.5-5..

Kamtarin,M.(2012).The Effect of Electronic Word of Mouth, Trust and Perseived value on Behavioral Intention from Perspective of Consumers. International Journal of Academic Research in Economics and Management Sciences. Vol1, no.4 
Keller, K.L. (2008). Strategy Brand Management (Building, Measuring, And Managing Brand Equity), 3rd Edition. New Jersey : Prentice Hall

Kim, D. J., Ferrin, D. L., dan Rao, H. R. (2008). A Trust-Based Consumer Decision-Making Model in Electronic Commerce: The Role of Trust, Perceived Risk, and Their Antecedents. Decision Support Systems, 44 , 544-564.

Lee, K. dan Koo, D. (2012). Effects of Attribute and Valence of eWOM on Message Adoption: Moderating Roles of Subjective Knowledge and Regulatory Focus. Computers in Human Behavior. 28(5), pp.1974-1984

Lee, M., Rodgers, S. dan Kim, M. (2009). Effects of Valence and Extremity of eWOM on Attitude toward the Brand and Website. Journal of Current Issues \& Research in Advertising. 31(2), pp.1-11

Lin, N. H., dan Lin, B.S. (2007). The Effect of Brand Image and Product Knowledge on Purchase Intention Moderated by Price Discount. Journal of International Management Studies

Mowen, J.C., dan Michael, M. (2002). Organization Behavior, Terjemahan Dwi Kartini. Bandung: FE Universitas Padjajaran,

Sekaran, U. (2006). Research Methods for Business: A Skill Building Approach. Jakarta: Elex Media Komputindo.

Shukla, P. (2010). Impact of Interpersonal Influences, Brand Origin and Brand Image on Luxury Purchase Intentions: Measuring Interfunctional Interactions and a CrossNational Comparison. Journal of World Business. Vol. 46 No. 2, pp. 242-52.

Thurau-Hennig, G., K.P., Walsh, G., dan Gremier, D,D. (2004). Electronic Word-Of Mouth via Consumer-Opinion Platforms: What Motives Consumers to Articulate Themselves On The Intenet?". Journal Of Interactive Marketing. Vol.18, No.1.

Tjiptono,F.(2005). Brand Management And Strategy.Yogyakarta :Andi Offset

We are Social. (2016). Annual Report 2016. UK

Zhu, F., dan Zhang, X. (2010). Impact of Online Consumer Reviews on Sales: The Moderating Role of Product and Consumer Characteristics. Journal of Marketing. 74(2), pp.133148. 